\title{
Characterization of young graduates perceiving underemployment: Assessment of well-being and discomfort associated with this perception
}

\author{
Juan Gabriel Ocampo-Palacio; Viviola Gómez Ortiz
}

Cómo citar este artículo:

Ocampo-Palacio, J. G., \& Gómez Ortíz, V. (2021). Characterization of young graduates perceiving underemployement: Assessment of well-being and discomfort associated with this perception. Acta Colombiana de Psicología, 24(2), 23-34. https:// www.doi.org/10.14718/ACP.2021.24.2.3

Recibido, febrero 19/2020; Concepto de evaluación, febrero 22/2021; Aceptado, abril 19/2021

\author{
Juan Gabriel Ocampo-Palacio ${ }^{1}$ \\ ORCID: https://orcid.org/0000-0001-9514-4055 \\ Universidad del Rosario, Bogotá Colombia \\ Viviola Gómez Ortiz ${ }^{2}$ \\ ORCID: https://orcid.org/0000-0002-1066-9483 \\ Universidad de los Andes, Bogotá, Colombia.
}

\begin{abstract}
Previous research has shown that subjective underemployment is inversely associated to job satisfaction, psychological well-being and health. To our knowledge, the current is the first study that explores subjective underemployment in undergraduates in Colombia. One hundred and forty-two workers participated in a correlational, and comparative study. Results replicated previous findings: as subjective underemployment perception increased, job satisfaction and general life satisfaction decreased. Significant differences were found in the indicators of job satisfaction and general life satisfaction among those who perceive underemployment and those who do not. Finally, the potential role of subjective underemployment on employees' health is discussed.

Keywords: subjective underemployment, job satisfaction, well-being, distress, effort-reward imbalance.
\end{abstract}

\section{Caracterización de jóvenes egresados que perciben subempleo: evaluación del bienestar y malestar asociadas a esta percepción}

Resumen

\begin{abstract}
Investigaciones previas han demostrado que el subempleo subjetivo está inversamente asociado a la satisfacción laboral, el bienestar psicológico y la salud. Hasta donde conocemos, este es el primer estudio que explora el subempleo subjetivo en egresados de pregrado en Colombia. Ciento cuarenta y dos trabajadores participaron en un estudio correlacional y comparativo. Los resultados replicaron hallazgos previos: a medida que aumentaba la percepción de subempleo subjetivo, disminuían la satisfacción laboral y la satisfacción con la vida en general. Se encontraron diferencias significativas en los indicadores de satisfacción laboral y satisfacción con la vida en general entre quienes perciben subempleo y quienes no. Por último, se discute el potencial ro del subempleo subjetivo en la salud de los empleados.

Palabras clave: Subempleo subjetivo, satisfacción con el trabajo, bienestar, malestar, desbalance esfuerzo-recompensa.
\end{abstract}

\footnotetext{
1 Juan Gabriel Ocampo-Palacio. Ms. Assistant Professor, School of Medicine and Health Sciences, Psychology Program, GI People, Family and Society Research Group, Universidad del Rosario, Bogotá, Colombia. Correspondence: juan.ocampo@urosario.edu.co 2 Viviola Gómez Ortiz PhD. Associate Professor, Director of Stress and Health Research Group, School of Social Sciences, Psychology Department. Universidad de los Andes, Bogotá, Colombia.
} 


\section{Introduction}

Underemployment is a condition wherein individuals perceive a discrepancy between the work assigned to them and their academic level or work experience, as well as the underuse of their skills and knowledge and income below their expectations. The literature shows that this is a problem for workers, especially for young people who are early in their career and faced with different situations such as the contradiction between the tasks assigned to them and their academic level or work experience, in addition to income below what was expected, among other aspects (Moya, 2014; Verbruggen et al., 2015). In this sense, studying underemployment is of great importance considering that this condition can affect the perception of the quality of work and, as a consequence, the workers' well-being and health. In fact, Peralta (2011) highlights that work is considered a relevant factor for people because it is an activity wherein a large amount of their time is spent. It is a factor of socialization and, in addition, it is considered an element that binds people to reality. Also, as Jahoda (1981, 1982) propose, the work and be employed is a factor that brings benefits to the individuals (income and psychological needs). Furthermore, work is a factor that determines the individuals' well-being and health (Anderson \& Winefield, 2011) and can ensure health equity (Benach et al., 2007).

Job insecurity, informality and unemployment: A brieflook

In recent decades, a fluctuating economic situation, both worldwide and in Colombia has been witnessed. This situation has resulted in various problems significantly affecting working people. Hence, concepts such as unemployment, informality, insecurity, and underemployment are exacerbated in the labor market. Although all these concepts refer to deficient working conditions, they have distinct meanings.

Unemployment has been defined as the condition of those who want to work, actively seek work and are willing to work immediately (Ramírez, 2002). In Colombia, the National Administrative Department of Statistics (DANE, for its Spanish acronym) (2020a) estimate that the unemployment rate during the month of december was $10.5 \%$.

On the contrary, informality is becoming increasingly important globally and locally. According to Tokman (2009), the origins of this concept refer to the employment report by the International Labor Organization (ILO) on Kenya in 1972 , where it is recognized that the main problem is not unemployment, but the working conditions that generate insufficient income for survival. In addition, informality has been associated with the lack of legal records or licenses to carry out the activity (Martínez-Veiga, 2009). In Colombia, the DANE (2020b) estimated that in the period of octoberDecember 2019 there was an informality rate of $47.6 \%$ in 23 cities and metropolitan areas.

Finally, job insecurity is a concept used to refer to the conditions of lack of job security for workers. Authors such as McDowell et al. (2009) have described insecurity using the ILO's definition, which argues, "job insecurity is the employment relationship lacking security" (p. 8). They also add that there is a wide range of ways to be hired, which give rise to job insecurity, including short-term work, casual contracts or contracts without a clear definition of time, work for employment agencies, or outsourcing. It is important to note that the quality of work is determined by a series of factors that are an objective expression of labor market institutions and universally accepted norms (such as physical working conditions, income, and social security, among others). However, there are also certain subjective factors that are linked to job satisfaction and that are related to the objective characteristics of job quality (Farné et al., 2012). One of those factors is underemployment.

\section{Underemployment}

It is difficult to establish a single definition of underemployment that can encompass all the elements surrounding the term given the various areas that have worked to conceptualize it. Authors such as McKee \& Harvey (2011), for example, establish that an employee is underemployed when he/she works in a job that is below his/her abilities. On the contrary, some definitions consider underemployment involves people employed for less hours than a legal workday (Bonnal et al., 2009; Puyana et al., 2011; Wilkins, 2007; ILO, 2014). Other authors claim that underemployment occurs when an individual is in a field of work different than his or her educational area, involuntarily works on a parttime basis (willing to work more hours), has a low income and when there is an imbalance between skills possessed and those required by the activities of the position (Bell \& Blanchflower, 2019; Cymbranowicz, 2016; De Moortel et al., 2018; Feldman, 1996; Feldman et al., 2002; Friedland \& Price, 2003; Glyde, 1977; Kaur et al., 2020; Lauterbach, 1977; Mousteri et al., 2020). Underemployment can be considered both a subjective and an objective condition since people can be considered objectively underemployed when they have a higher educational level than that required for the position, while the subjective condition implies that individuals self-classify as such (Gómez, 2008).

Given the lack of a comprehensive definition and both its subjective and objective positions, in this article we propose to define subjective underemployment as the perception 
individuals have of the imbalance between their education, knowledge, and abilities and those that the position they currently hold demands or requires. This in turn can be expressed in the perception of their characteristics being underutilized or the perception of being overqualified for the position that they hold.

The concept of imbalance is relevant to explain the possible association between underemployment and stress in individuals who are faced with this condition, which would be the reason for developing health and welfare problems. In fact, explaining why and how the imbalance between demands and rewards leads to conditions of poor health and well-being is the intention of the model developed by Johannes Siegrist (2002), called "effort-reward imbalance." This model proposes that the exchange mediated by social roles (work role in this case) is guided by cost-benefit reciprocity contracts. According to Siegrist (2002), in addition to the importance that this contract has for social functioning, this exchange of reciprocity can have both beneficial and detrimental effects on the individuals' health and well-being. Thus, in those conditions where contracts of reciprocity (effort-reward) are not held, the health and well-being of individuals may deteriorate. This failed reciprocity can be reflected in the situation wherein individuals perceive that their skills, knowledge, and education are not being used fully.

\section{Underemployment prevalence}

The prevalence of underemployment worldwide is not entirely clear, largely due to the different definitions used. The data reported in different parts of the world ranges between $0.4 \%$ and $8.8 \%$ (Hilbrecht et al., 2017; Mckee \& Harvey, 2011; Tam, 2010; Thompson, et al., 2013; Winefield, 2002; Walling \& Clancy, 2010; Wilkins \& Wooden, 2011). In Colombia, the figures for the period of October-December 2019 show a subjective underemployment rate of $24.6 \%$ and an objective underemployment of $10.2 \%$ (DANE, 2020a). As regards the demographic characteristics of this population, both in Colombia and in other countries, the literature shows that it is generally men, between 18 and 24 years old, who perceive underemployment most (Henao, 2000; Puyana et al., 2013; Winefield et al., 1991).

\section{Psychological consequences of underemployment}

Different studies were identified in the literature that have established an association between subjective underemployment and a decrease in job satisfaction, psychological well-being, and health, factors that deteriorate quality of life for working individuals (Allan, et al., 2020; Anderson \& Winefield, 2011; Bell \& Blanchflower 2019; Burris, 1983;
Daly \& Delaney, 2020; Dooley et al., 2000; Feldman et al., 2002; Heyes \& Tomlinson, 2021; Hilbrecht et al., 2017; Jones-Johnson \& Johnson, 1992; Kamerāde \& Richardson, 2018; Kim \& Allan, 2020; Malenfant et al., 2007; Tam, 2010; Winefield et al., 1991). Additionally, positive correlations have been established between subjective underemployment and depression, while negative correlations were associated with positive affect (Feather \& O'Brien, 1986b). In contrast, the perception of underemployment is a potential stressor that can compromise the workers' perceived health and well-being and be associated with indicators of depression and low self-esteem (Friedland \& Price, 2003; Johnson, 1986; Johnson \& Johnson, 1996; Kahn \& Morrow, 1991).

In a research conducted by Jones-Johnson and Johnson (1992), a significant and positive relationship between a high perception of underemployment and stress reactions was found, which would indicate that the greater the perception of subjective underemployment, the greater the probability that the person will experience psychosomatic responses, depression, frustration, hostility, and insecurity. Another relevant study of underemployment is the research conducted by Burris (1983), which - through interviews with office workers at the same hierarchical level-although in different contexts, evaluated their attitudes and behavior toward the job. He concluded that among workers at the same hierarchical level with different academic backgrounds, there were different perceptions of overqualification for their jobs. Those with a greater perception of imbalance between their educational and job requirements showed a certain level of dissatisfaction and stronger negative feelings. Workers with university degrees also perceived a certain level of reverse discrimination (rejection by their peers at the same hierarchical level but with a lower educational level).

For the present research study, we reviewed the existing literature on underemployment in Latin America and Colombia, particularly the characteristics of the population who perceive underemployment and the possible consequences on health and well-being. The results showed that there is little work in this regard in our context (García-Ubaque et al., 2012; Moya, 2014; Petter Pérez \& Moreno Hurtado, 2019; Restrepo \& Rivas, 2013). One of the few documents identified was by Peralta (2011), which deals mainly with the meanings that people attribute to employment changes and the transition between formality and informality. Peralta found that many people see employment contracts as a representation of stability, security, and other characteristics that contribute to the professional development. Furthermore, for Colombian workers this transition supports the ideal of being an independent worker, which seems to be the way in which individuals face uncertainty and insecurity. 
The review allowed us to identify three relevant aspects that justify the study. First, there is no definition that covers all the elements of the condition of perceiving underemployment or being underemployed; second, there are few studies in Colombia that have sought to identify possible associations between underemployment and mental health, an aspect that represents a gap in the labor market research and their relationship with health and well-being; and, finally, there is a lack of clarity regarding the demographic, educational, and employment characteristics of the population that perceives underemployment in Colombia, particularly among young graduates, as previously identified in the literature. This research sought to carry out an initial approach to the problem of underemployment within the Colombian context based on the demographic, educational, and employment characterization of young graduates in the city of Bogotá; additionally, some psychological states and their association with subjective underemployment were evaluated. Positive indicators (psychological well-being and job satisfaction) and negative indicators (general distress) of the psychological state were evaluated. Given that the trait of positive and negative affect can be related to all the variables to be evaluated (Finch et al., 2015) and that these will be evaluated based on self-reports, the affective trait was included as a control variable. The independent variable is subjective underemployment (perception of underemployment).

The objectives established for this correlational and comparative research study were the following:

1. to characterize the population of recent young university graduates who perceive themselves as underemployed and identify how they differ from those who do not perceive themselves that way;

2 . to establish the distress and psychological wellbeing conditions prevalent in young people who just graduated from university and who perceive themselves as underemployed; and

3. to establish whether there are significant differences in the psychological states between recent young graduates who perceive themselves as underemployed and those who do not.

\section{Methods}

Design and type of study

To stablish the associations between variables and compare them, we use a correlational and comparative design; the type of study was Cross-sectional (Hernández et al., 2010).

\section{Participants}

The participants of this research project were selected in a non-probabilistic manner, following a convenience sampling, which consisted of 142 professionals (51 men and 91 women) with undergraduate degrees obtained between 2011 and 2014. The participants were selected from different universities in Bogotá and by various electronic means. The main inclusion criterion was that they were working and were residents of Bogotá or nearby areas at the time they responded to the questionnaire.

\section{Instruments}

A questionnaire was prepared to collect participant socio-demographic, educational, and employment data. To measure the perception of underemployment, a questionnaire of subjective underemployment was developed, referencing the instruments previously used in various studies (Feldman et al., 2002; Feldman \& Turnley, 1995; Jones-Johnson \& Johnson, 1992) and based on the definition proposed in this study. The development of this questionnaire was required since there is no validated instrument in Colombia that fully assesses the concept of objective and subjective underemployment. The questionnaire consists of nine statements that are rated on a Likert scale with four response options: strongly disagree (1), disagree (2), agree (3) and strongly agree (4). A pilot was carried out with academic peer review on the relevance and structure of the items. Subsequently, the questionnaire was applied to a group of 9 people with characteristics similar to those of the target sample. The internal consistency of the questionnaire assessed with the sample of participants $(N=142)$ was .81 . Some examples of the items used to assess the discrepancy and non-use of skills were the following: "I feel I have more skills than those required for my current position"; "there is a discrepancy between what I expected from employment and what the position requires from me."

To assess job and life satisfaction, the version adapted to Spanish by Paris (2008) from the questionnaire developed by Shouksmith (1990) was used, known as the job and life satisfaction scale. This instrument is composed of 12 items grouped into two dimensions. The first dimension consists of ten items that assess job satisfaction, while the second dimension assesses general life satisfaction. In this study, we obtained $\alpha=.89$ for job satisfaction and $\alpha=.58$ for general life satisfaction.

To assess distress, the General Health Questionnaire (GHQ-28) developed by Goldberg (1972) was implemented. This questionnaire assesses self-perceived health; that is, how individuals assess their sate of anxiety, depression, psychosomatic symptoms and social adjustment. In this 
research project, we used the 28-item version implemented in Colombia with good psychometric indicators (Gómez, 2012). Lobo et al. (1986) completed its adaptation to the Hispanic population and it is composed of four subscales: psychosomatic symptoms, anxiety, depression, and social adjustment. Each scale has seven items, which are answered on a Likert scale that varies from $1=$ not at all, to $4=$ more than usual. A higher score on the scale indicates greater distress. In this study, the following alphas were obtained: psychosomatic symptoms $(\alpha=.86)$, anxiety $(\alpha=.88)$, social adjustment $(\alpha=.67)$, depression $(\alpha=.87)$.

To assess psychological well-being, the Spanish adaptation of the short version prepared by Díaz et al. (2006) from the Ryff Scale (1989a) was used. This questionnaire is composed of 29 items that evaluate six dimensions: selfacceptance, positive relationships, autonomy, environmental control, purpose in life, and personal growth. The rating format of this scale ranges from 1 (strongly disagree) to 6 (strongly agree). The alphas obtained in this study were: self-acceptance $(\alpha=.78)$, positive relationships $(\alpha=.79)$, autonomy $(\alpha=.57)$, environmental control $(\alpha=.69)$, purpose in life $(\alpha=.85)$ and personal growth $(\alpha=.60)$.

To measure the affective trait, the Spanish version adapted by Sandín, et al. (1999), from the questionnaire developed by Watson et al. (1988) called PANAS, was used. The scale has 20 words divided into two dimensions: positive affect (PA) and negative affect (NA). The rating scale varies between 5 (Extremely), 4 (Quite a bit), 3 (Moderately), 2 (Somewhat) and 1 (Very little or none). The alphas obtained in this study were $\alpha=.87$ for PA and $\alpha=.86$ for NA.

\section{Ethical considerations}

This research was carried out under the regulations of the Code of Ethics and Bioethics of the practice of Psychology in Colombia. This study was classified as a research with minimal risk (Resolución 8430 of 1993), since no type of intervention or modification on psychological or social variables in the participating individuals, in addition to be a study with standard research techniques, including an informed consent. This study had the approval of the Ethics Committee of the Faculty of Social Sciences of the Universidad de los Andes, Bogotá, Colombia.

\section{Procedure}

We contacted some public and private higher education institutions ${ }^{1}$ in Bogotá at their graduate offices or university programs/departments. We also used various electronic tools

1 We formally contacted the following universities: Universidad del Rosario, Universidad de los Andes, Universidad Nacional de Colombia, and Universidad Católica de Colombia. such as social networks, electronic newsletters ${ }^{2}$ or academic web pages with the goal of reaching a greater number of graduates belonging to universities that were not formally contacted. The Survey Monkey platform was used for the online questionnaire and, once we obtained approval from the universities contacted, they sent the invitation via e-mail to the graduates including a brief description of the project's objective and the link where they would find the informed consent and the questionnaire. The same procedure was used for social networks and electronic newsletter.

\section{Results}

First, the demographic, educational, and employment description of research participants is presented below. Subsequently, the results on the state of distress and well-being of people who perceive underemployment are presented and how they differ from those who do not perceive it. 259 people had responded to the questionnaire. Subsequently, a total of 117 people who did not meet the inclusion criteria or who did not complete the questionnaire were discarded. Accordingly, the final sample size was $N=142$. The participants' average age was 26.01 $(S D=3.21)$; the highest percentage of the sample was in the age range between 23 and 27 years (see Table 1). The results showed higher participation from women (64.1\%) and single individuals (82.4\%).

Table 2 describes the participants' educational characteristics. Here, we observe that the majority of participants belong to the field of Social and Human Sciences (49.3\%), and attended a private university $(85.9 \%)$. Table 3 shows the employment characteristics of the participants. Most people have been working for more than 2 years $(35.2 \%)$ and belong to the service sector (31\%). We can also observe that, for the most part, people work between 40 and 45 hours a week (40.1\%), and their salary is over 2,500,000 pesos $(35.2 \%)$.

The results in measurements of psychological well-being, PA, and NA showed high levels of distress, well-being, and PA and low levels of NA (see Table 4). Similarly, general life satisfaction and job satisfaction are relatively high.

Table 5 presents the categories of different underemployment perception. To carry out the division into these four categories, the $25,50,75$ percentiles of the distribution on the variable were taken as cut points.

Subgroups of underemployment perception were compared on their demographic, education, and employment

\footnotetext{
2 For example, the Electronic Newsletter of School HealthTIPICA
} 
Table 1.

Demographic characteristics of the participants

\begin{tabular}{|c|c|}
\hline Demographic characteristics & Percentage $(\%)$ \\
\hline \multicolumn{2}{|l|}{ Age (years) } \\
\hline 22 or under & 2.1 \\
\hline Between 23 and 27 & 77.5 \\
\hline Between 28 and 32 & 14.1 \\
\hline Between 33 and 37 & 5.6 \\
\hline Over 37 & 0.7 \\
\hline \multicolumn{2}{|l|}{ Sex } \\
\hline Male & 35.9 \\
\hline Female & 64.1 \\
\hline \multicolumn{2}{|l|}{ Originally from } \\
\hline Bogotá & 73.9 \\
\hline Outside Bogotá & 26.1 \\
\hline \multicolumn{2}{|l|}{ Current residence } \\
\hline Bogotá & 92.3 \\
\hline Outside Bogotá & 7.7 \\
\hline \multicolumn{2}{|l|}{ Civil status } \\
\hline Single & 82.4 \\
\hline Cohabitation & 9.2 \\
\hline Married & 7.7 \\
\hline Divorced/separated & 0.7 \\
\hline \multicolumn{2}{|l|}{ Children } \\
\hline Yes & 13.4 \\
\hline No & 86.6 \\
\hline \multicolumn{2}{|l|}{ Number of children } \\
\hline 1 & 9.2 \\
\hline 2 & 2.8 \\
\hline 3 & 0.7 \\
\hline \multicolumn{2}{|l|}{ Socioeconomic stratum } \\
\hline 1 & 0.7 \\
\hline 2 & 14.1 \\
\hline 3 & 35.9 \\
\hline 4 & 27.5 \\
\hline 5 & 9.2 \\
\hline 6 & 12.7 \\
\hline
\end{tabular}

Table 2.

Educational characteristics of the participants

\begin{tabular}{cc}
\hline Educational characteristics & Percentage (\%) \\
\hline Knowledge field & 49.3 \\
Social and Human Sciences & 16.9 \\
Economics, Administration, Account- & \\
ing and related areas & 27.5 \\
Engineering, Architecture, & 4.2 \\
Urban Planning and related areas & 0.7 \\
Mathematics and Natural Sciences & 0.7 \\
Visual Arts, Fine Arts and related areas & \\
Veterinary, Agronomy and related areas & 85.9 \\
Type of University & 14.1 \\
Private & \\
Public & 4.2 \\
Graduation Year & 48.6 \\
2011 & 42.3 \\
2012 & 4.9 \\
2013 & \\
2014 &
\end{tabular}

Table 3.

Employment characteristics of the participants

\begin{tabular}{|c|c|}
\hline Employment characteristics & Percentage $(\%)$ \\
\hline \multicolumn{2}{|l|}{ Time employed } \\
\hline Between 1 month and 6 months & 14.8 \\
\hline Between 6 months and 1 year & 15.5 \\
\hline Between 1 year and 1 and a half years & 14.1 \\
\hline Between 1 and a half years and 2 years & 20.4 \\
\hline More than 2 years & 35.2 \\
\hline \multicolumn{2}{|l|}{ Economic sector } \\
\hline Services & 31 \\
\hline Other sectors & 19 \\
\hline Health & 14.8 \\
\hline Educational & 12.7 \\
\hline Financial & 7.7 \\
\hline Infrastructure & 7 \\
\hline Technology & 6.3 \\
\hline Telecommunications & 0.7 \\
\hline \multicolumn{2}{|l|}{ Current position classification } \\
\hline Professional & 59.9 \\
\hline Analyst & 14.8 \\
\hline Coordinator & 8.5 \\
\hline Assistant & 7 \\
\hline Adviser & 6.3 \\
\hline Manager & 2.8 \\
\hline Director & 0.7 \\
\hline \multicolumn{2}{|l|}{ Number of dependents } \\
\hline 0 & 65.5 \\
\hline Between 1 and 3 & 23.9 \\
\hline Between 3 and 6 & 4.2 \\
\hline Between 6 and 10 & 1.4 \\
\hline More than 10 & 4.9 \\
\hline \multicolumn{2}{|l|}{ Working hours (per week) } \\
\hline Between 24 and 30 & 9.2 \\
\hline Between 30 and 35 & 5.6 \\
\hline Between 35 and 40 & 12.7 \\
\hline Between 40 and 45 & 40.1 \\
\hline Over 45 & 32.4 \\
\hline \multicolumn{2}{|l|}{ Wage income (Colombian pesos) } \\
\hline Between 616,000 and $1,000,000$ & 6.3 \\
\hline Between $1,000,000$ and $1,500,000$ & 19.7 \\
\hline Between $1,500,000$ and $2,000,000$ & 19.7 \\
\hline Between $2,000,000$ and $2,500,000$ & 19 \\
\hline More than $2,500,000$ & 35.2 \\
\hline
\end{tabular}

Table 4.

Means, standard deviations and alphas of the scales.

\begin{tabular}{ccccc}
\hline Scale & Rank & $M$ & $S D$ & Alpha \\
\hline Job satisfaction & $1-5$ & 3.56 & 0.84 & .89 \\
General life satisfaction & $1-5$ & 3.76 & 0.82 & .58 \\
$\begin{array}{c}\text { Psychological well- } \\
\text { being }\end{array}$ & $1-5$ & 3.97 & 0.52 & .90 \\
$\begin{array}{c}\text { Distress (General } \\
\text { Health Scale) }\end{array}$ & $28-112$ & 57.36 & 16.47 & .91 \\
$\begin{array}{c}\text { Subjective underem- } \\
\text { ployment }\end{array}$ & $1-4$ & 2.57 & 0.57 & .81 \\
Positive affect & $10-50$ & 36.91 & 6.73 & .87 \\
Negative affect & $10-50$ & 19.58 & 6.70 & .86 \\
\hline
\end{tabular}


Table 5.

Categories of subjective underemployment.

\begin{tabular}{ccc}
\hline Category & Frequency & Percentage (\%) \\
\hline $\begin{array}{c}\text { No perception of } \\
\text { underemployment } \\
\begin{array}{c}\text { Low perception of } \\
\text { underemployment }\end{array}\end{array}$ & 31 & 21.8 \\
$\begin{array}{c}\text { Moderate perception } \\
\text { of underemployment } \\
\begin{array}{c}\text { Perception of } \\
\text { underemployment } \\
\text { Total }\end{array}\end{array}$ & 20 & 20.4 \\
\hline
\end{tabular}

characteristics but the results did not show significant differences between the four groups.

\section{Distress and well-being indicators}

The data analysis showed that people with a high perception of underemployment have lower scores in the scales of general life satisfaction, job satisfaction, and psychological well-being compared to people who do not perceive it or who perceive it in a moderate way (see Table 6). The score for the distress scale showed similar results, that is, lower scores on people with high perception of underemployment compared to people who do not perceive it or who perceive it in a moderate way.

ANCOVAS were conducted to control the effect of PA and NA on the psychological well-being, job satisfaction, life satisfaction, and distress in accordance with the perception of underemployment. The results showed that there were no significant differences in psychological well-being $(F(3,138)=0.991 p>.05)$ and in the distress indicator $(F(3,138)=0.520 p>.05)$. However, they did show significant differences for job satisfaction $(F(3,138)=7.340$, $p<.01)$, as well as in general life satisfaction $(F(3,138)=$ 4.710, $p<.05$ ) (see Tables 7 and 8).

Furthermore, correlations were carried out to establish associations between subjective underemployment and indicators of distress and well-being (see Table 9). The results showed that after controlling the affect, the indicators of psychological well-being $(r=-.143 ; p>.01)$ and distress $(r=.122 ; p>.01)$ were not significantly related to subjective underemployment whereas job satisfaction $(r=$ -.443; $p<.01)$ and general life satisfaction $(r=-.408 ; p<.01)$ are associated with negative and significant subjective

Table 6.

Means and standard deviations of the indicators of discomfort and well-being in people who perceive underemployment.

\begin{tabular}{ccccccccccc}
\hline & & \multicolumn{2}{c}{$\begin{array}{c}\text { Perception of under- } \\
\text { employment }\end{array}$} & \multicolumn{2}{c}{$\begin{array}{c}\text { Moderate perception } \\
\text { of under-employment }\end{array}$} & $\begin{array}{c}\text { Low perception of } \\
\text { under-employment }\end{array}$ & $\begin{array}{c}\text { No perception of } \\
\text { under-employment }\end{array}$ \\
\hline Scale & Rank & $M$ & $S D$ & $M$ & $S D$ & $M$ & $S D$ & $M$ & $S D$ \\
\hline $\begin{array}{c}\text { Job satisfaction } \\
\text { General life satis- } \\
\text { faction }\end{array}$ & $1-5$ & 3.25 & 0.82 & 3.25 & 0.59 & 3.70 & 0.75 & 4.27 & 0.67 \\
$\begin{array}{c}\text { Psychological } \\
\text { well-being }\end{array}$ & $1-5$ & 3.43 & 0.87 & 3.55 & 0.60 & 4.01 & 0.67 & 4.32 & 0.61 \\
$\begin{array}{c}\text { Discomfort (gen- } \\
\text { eral health) }\end{array}$ & $28-112$ & 62,2 & 17.73 & 57.35 & 15.43 & 51.75 & 15.80 & 52.83 & 12.28 \\
\hline
\end{tabular}

Table 7.

ANCOVA for job satisfaction.

\begin{tabular}{clllll}
\hline & \multicolumn{5}{c}{ ANCOVA } \\
\hline Indicator & df1 & df 2 & $F$ & $P$ & Post-hoc Sidak \\
\hline
\end{tabular}

No perception of underemployment*low perception of underemployment

No perception of underemployment*moderate perception of 
Table 8.

ANCOVA for general life satisfaction.

\begin{tabular}{ccccccc}
\hline & \multicolumn{3}{c}{ ANCOVA } \\
\hline Indicator & df1 & df 2 & $F$ & $P$ & Post-hoc Sidak \\
General life satisfaction & 3 & 138 & 4.710 & .004 & $\begin{array}{c}\text { No perception of underemployment*low } \\
\text { perception of underemployment } \\
\text { underemployment*moderate perception of } \\
\text { underemployment }\end{array}$ \\
\hline
\end{tabular}

Table 9.

Correlation between the subjective underemployment scale and the indicators of discomfort and well-being controlling the affective trait

\begin{tabular}{lcccc}
\hline & $\begin{array}{c}\text { Psychological } \\
\text { well-being }\end{array}$ & General discomfort & General life satisfaction & Job satisfaction \\
\hline Subjective underemployment & -.143 & .122 & $-.408^{* *}$ & $-.443 * *$ \\
\hline
\end{tabular}

$* *$ The correlation coefficients are significant at the level of $p<.01$

underemployment, which indicates that the higher the scores in the subjective underemployment scale, the lower the scores in job satisfaction and general life satisfaction.

\section{Discussion}

Regarding the goal of characterizing the population that perceives underemployment it is not possible to assert they have specific demographic, educational, or employment conditions. One aspect that had been of special interest for this research was the age of participants, given that in different articles it was pointed out that the young population was the most affected by underemployment (Henao, 2000; Moya, 2014; Puyana et al., 2011). The age difference was not significant among the population that perceived underemployment from the population that did not perceive it. Besides, there were no significant differences with respect to the year they graduated. This result could be explained due to the sample size and its demographic, employment, and educational homogeneity. Future research should seek greater demographic, employment, and educational heterogeneity, which would allow the identification of differentiating characteristics.

In line with what was expected, associations among subjective underemployment with job satisfaction and general life satisfaction were found. This result indicates that a higher perception of underemployment is associated with lower job and general life satisfaction. This is consistent with the literature (Allan et al., 2020; Bell \& Blanchflower 2019; Friedland \& Price, 2003; Kim \& Allan, 2020).
With respect to psychological well-being and distress, the associations with perceived underemployment were not significant. It is possible that to experience distress and psychological well-being people need to be in a situation of subjective underemployment for a longer period. This assertion derives from the prediction of the effort-reward model in the sense that chronic and adverse employment conditions have a long-term impact on people's health and well-being (Siegrist, 2002). It is possible that health outcomes are affected less quickly than affective variables such as job and life satisfaction (Perilla \& Gómez, 2017). Future research should try to use longitudinal designs, which allow for a much more detailed monitoring of health and well-being in people who perceive underemployment and, in this way, establish a possible causal relationship between these variables.

Regarding the last research question, significant differences were only found for job satisfaction and life satisfaction between those who perceive underemployment and those who do not perceive it. However, as noted above, if the condition of underemployment persists over time, it is very likely that health and well-being will deteriorate in the long term. In fact, the concept of effort-reward imbalance presented by Siegrist (2002) is based on the assumption that the chronic lack of reciprocity between efforts and rewards leads to adverse effects on the individuals' health and well-being. The lack of reciprocity brings results in other types of consequences for individuals such as job burnout (Siegrist, 2002).

Bad working conditions have a high positive correlation with high blood pressure (Juárez-García, 2008). It is likely 
that people who remain in the condition of underemployment in the long term may have consequences on their blood pressure and develop cardiovascular diseases. JuárezGarcía (2008) even considers that employment seen from a multilevel perspective explains a social pattern of cardiovascular diseases and their greatest risks, so understanding the condition of subjective underemployment becomes more relevant in light of the risks to the individuals' health.

One of the main challenges for this research study was related to the definition of the concept of underemployment, which involved operationalizing it and developing a measurement. Therefore, having taken an initial approach to this condition in the country is relevant to the extent that it not only sought to establish the main demographic, educational, and occupational characteristics of the population that perceives underemployment, but also to propose a definition that would cover the different elements that substantiate the concept of underemployment in the literature.

In contributing to the psychological literature, this study provide an interesting contribution because the results have shown that the non-utilization of education, skills, and knowledge are associated with decreased job satisfaction and general life satisfaction. In fact, this work reveals a scarcely studied condition of the labor market that is present among Colombian workers and that has a negative impact on their well-being and quality of life. Considering the above, this will make it easier for subjective underemployment to be studied more in the future and provide even more data to design preventive measures in organizations.

Underemployment may be a factor that can be analyzed using the Colombian legislation on psychosocial risk (Resolución 2646 of 2008), specifically, in the content of the tasks and the person-task interface where the knowledge and skills that workers have, among others, are assessed in relation to the task's demands, their levels of initiative, and autonomy. In this sense, assessing psychosocial risk factors at work can contribute to minimize the perception of underemployment and its consequences on health, job satisfaction, and well-being in people, particularly at a primary prevention level such as the one established by Landsbergis (2008) - by attacking the root or structure of the problem.

Finally, considering a macro level, this initial approach to subjective underemployment in young graduates could be an input for decision-making to improve the quality of work, entry into the workforce (Ley 1429 of 2010 and Ley 1780 of 2016) and the well-being of the working population. At the educational level, it could contribute to undergraduate programs in preparing future graduates to face the changing conditions of the labor market, particularly situations where professionals faced the underutilization of their academic training, skills and knowledge.

Some of the limitations during the development of this research were related to the design of the study and the data collection process. First, since it is a cross-sectional design, it is not possible to establish causality between the perception of underemployment and the indicators of health and well-being. Second, we expected more people to participate in this study, specifically, to have a greater representation of graduates from public and private universities with different education and work contexts. However, access to graduates was notably limited in some universities due to Ley 1582 of 2012 that regulates the protection of personal data. In this sense, it is clear that the conclusions presented here are limited by the composition of the sample. For future research, other sources for data collection may be considered, such as companies in different sectors of the economy.

\section{References}

Allan, B. A., Rolniak, J. R., \& Bouchard, L. (2020). Underemployment and well-being: Exploring the dark side of meaningful work. Journal of Career Development, 47(1), 111-125. https://doi.org/10.1177/0894845318819861

Anderson, S. \& Winefield, A. (2011). The Impact ofUnderemployment on Psychological Health, Physical Health, and Work Attitudes. En D. Maynard \& D. Feldman (Ed.) Underemployment (pp. 165-185). New York: Springer.

Bell, D. N., \& Blanchflower, D. G. (2019). The well-being of the overemployed and the underemployed and the rise in depression in the UK. Journal of Economic Behavior \& Organization, 161, 180-196. https://doi.org/10.1016/j. jebo.2019.03.018

Benach, J., Muntaner, C., Santana, V. \& EMCONET network (2007). Employment Conditions and Health Inequalities: Final Report to the Commission on Social Determinants of Health (CSDOH). Employment Conditions Network (EMCONET) Geneva, WHO. Disponible en: www.who. int/social_determinants/resources/articles/emconet_who_ report.pdf

Bonnal, M., Lira, C., \& Addy, S. (2009). Underemployment and Local Employment Dynamics: New Evidence. The Review of Regional Studies, 39(3), 317-335. https://doi. org/10.52324/001c.8227

Burris, B. (1983). The Human Effects of Underemployment. Social Problems, 31(1), 96-110. https://doi. org/10.2307/800412

Cymbranowicz, K. (2016). The Phenomenon of Underemployment in Poland. Annales Etyka w Życiu Gospodarczym, 19(4) 35-51. Doi: $10.18778 / 1899-2226.19 .4 .10$ 
DANE (2020a). Boletín técnico: Principales Indicadores del Mercado Laboral. Recuperado de https://www.dane.gov. co/files/investigaciones/boletines/ech/ech/bol_empleo_ dic_19.pdf

DANE (2020b). Boletín técnico: Medición de empleo informal y seguridad social Trimestre octubre - diciembre 2019. Recuperado de https://www.dane.gov.co/files/investigaciones/boletines/ech/ech_informalidad/bol_ech_informalidad_oct19_dic19.pdf

De Moortel, D., Dragano, N., Vanroelen, C., \& Wahrendorf, M. (2018). Underemployment, overemployment and deterioration of mental health: the role of job rewards. International Archives OfOccupational And Environmental Health, 91(8), 1031-1039. https://doi.org/10.1007/s00420-018-1345-0

Díaz, D., Rodríguez, R., Blanco, A., Moreno, B., Gallardo, I., Valle, C. \& van Dierendonck, D. (2006). Adaptación española de las escalas de bienestar psicológico. Psicothema, 18(3), 572 - 577. http://www.psicothema.com/pdf/3255.pdf

Dooley, D., Prause, J. \& Ham-Rowbottom, K. (2000). Underemployment and Depression: Longitudinal Relationships. Journal of Health and Social Behavior, 41(4), 421-436. https://doi.org/10.2307/2676295.

Farné, S., Vergara, C. \& Baquero, N. (2012). La calidad del empleo y la flexibilización laboral en Colombia. En: S. Farné (Ed). La calidad del empleo en América Latina a principios del siglo XXI (119-164). Bogotá: Universidad Externado de Colombia

Feather, N. T. \& O’ Brien, G. E. (1986b). A longitudinal study of the effects of employment and unemployment on schoolleavers. Journal of Occupational Psychology, 59(2), 121-1 44. https://doi.org/10.1111/j.2044-8325.1986.tb00219.x

Feldman, D.C. (1996). The Nature, Antecedents and Consequences of Underemployment. Journal of Management, 22(3), 385-407. https://doi.org/10.1016/ S0149-2063(96)90030-6

Feldman, D.C. \& Turnley, W.H. (1995).Underemployment among recent business college graduates. Journal of Organizational Behavior, 16(6), 691-706. https://doi. org/10.1002/job.4030160708

Feldman, D.C., Leana, C.R. \& Bolino, M.C. (2002). Underemployment and relative deprivation among re-employed executives. Journal of Occupational and Organizational Psychology, The British Psychological Society, 75(4), 453471. https://doi.org/10.1348/096317902321119682

Finch, J.F., Baranik, L.E., Liu, Y. \& West, S.G. (2012). Phsycal health, positive and negative affect, and personality: A longitudinal analysis. Journal of Research in Personality, 46(5), 537-545. https://doi.org/10.1016/j.jrp.2012.05.013

Friedland, D.S. \& Price, R.H. (2003). Underemployment: Consequences for the Health and Well-Being of Workers. American Journal of Community Psychology, 32(1/2), 3345. https://doi.org/10.1023/A:1025638705649

García-Ubaque, J. C., Riaño-Casallas, M. I., \& BenavidesPiracón, J. A. (2012). Informalidad, desempleo y subempleo: Un problema de salud pública / Informal employment, unemployment and underemployment: a matter of public health. Revista de Salud Pública, (suppl 1), 138150. https://doi.org/10.1590/S0124-00642012000700012

Glyde, (1977). Underemployment: definition and causes. Journal of Economic Issues, 9(2), 245-260. https://doi.org /10.1080/00213624.1977.11503434

Goldberg, D. P. (1972). The detection of psychiatric Illness by Questionnaire. Londres: Oxford University Press.

Gómez, L.M. (2008). Subempleo, empleo inadecuado y bienestar. (Disertación doctoral sin publicar). Universitat Autònoma de Barcelona, Bellaterra- España. Disponible en http:/www.ecap.uab.es/secretaria/trebrecerca/lgomezr.pdf.

Gómez, V. (2012). Riesgos para la salud de profesores universitarios derivados de factores psicosociales-laborales. Bogotá D.C: Ediciones Uniandes.

Henao, M.L. (2000). Caracterización del subempleo y políticas para enfrentarlo. En: Instituto de políticas de DesarrolloIPD y DANE (eds). Subempleo y Bienestar Social. (155174). Bogotá: Editores.

Hernández, R., Fernández, C. \& Baptista, M. (2010). Metodología de la Investigación. McGraw Hill.

Heyes, J., \& Tomlinson, M. (2021). Underemployment and well-being in Europe. Human Relations, 74(8), 1240-1266. https://doi.org/10.1177/0018726720912297

Hilbrecht, M., Smale, B. \& Mock, S. E. (2017). The Relationship between Perceived Underemployment and Wellbeing: Evidence from Mid-Size Canadian Cities. Applied Research in Quality of Life, 12(3), 607-631. https://doi.org/10.1007/ s11482-016-9479-2

Jahoda, M. (1981). Work, employment and unemployment: Values, theories and approaches in social research. American Psychologist, 36(2), 1983-1991. https://doi. org/10.1037/0003-066X.36.2.184

Jahoda, M. (1982). Employment and unemployment: A socialpsychological analysis. London: Cambridge University Press.

Johnson, G. J. (1986). The effects of underemployment and being underpaid on psychological functioning among working men (Doctoral dissertation, University of Michigan, 1986). Dissertation Abstracts International, 47(6-A) 2339.

Johnson,G. J., \& Johnson,W. R. (1996). Perceived overqualification and psychological well-being. Journal of Social Psychology, 136(4), 435-445. https://doi.org/10.1080/002 24545.1996.9714025

Jones-Jhonson, G. \& Jhonson, W. (1992). Subjective Underemployment and Psychosocial Stress: The Role of Perceived Social and Supervisor Support.The Journal of Social Psychology, 132(1), 11-21. https://doi.org/10.1080/ 00224545.1992 .9924684

Juárez García, A. (2008). La perspectiva multinivel en las enfermedades cardiovasculares: El rol de las características 
psicosociales del trabajo. Psicologia.com, 12(1). http://psiqu.com/1-6466

Kahn, L. J., \& Morrow, P.C. (1991). Objective and subjective underemployment relationships to job satisfaction. Journal of Business Research, 22(3), 211-218. https://doi. org/10.1016/0148-2963(91)90002-F

Kaur, M., Goyal, P., \& Goyal, M. (2020). Individual, interpersonal and economic challenges of underemployment in the wake of COVID-19. Work, 67(1), 21-28. https://doi. org/10.3233/WOR-203249

Kamerāde, D., \& Richardson, H. (2018). Gender segregation, underemployment and subjective well-being in the UK labour market. Human Relations, 71(2), 285-309. https://doi. org/10.1177/0018726717713829

Kim, T., \& Allan, B. A. (2020). Underemployment and meaningful work: The role of psychological needs. Journal of Career Assessment, 28(1), 76-90. https://doi. org/10.1177/1069072718824004

Landsbergis, P. (2008). ¿Qué se debe hacer para prevenir los riesgos psicosociales en el trabajo? Archivos de Prevención de Riesgos Laborales, 11(1), 36-44. https://intervencionpsico.insst.es/Images/Resources/prevenir_r_psicosocial_trabajo.pdf

Lauterbach, A. (1977). Employment, Unemployment and Underemployment: A Conceptual Re-Examination. American Journal of Economics and Sociology, 36(3), 283298. https://www.jstor.org/stable/3486009

Ley 1780 de 2016. Diario Oficial No. 49.861, Cartagena D.T y C, Colombia, 2 de mayo de 2016.

Ley 1429 de 2010. Diario Oficial No. 47.937, Bogotá, Colombia, 29 de diciembre de 2010.

Ley 1582 de 2012, Diario Oficial No. 48.587, Bogotá, Colombia, 118 de octubre de 2012.

Lobo, A., Pérez-Echeverría, M. J., \& Artal, J. (1986). Validity of the scaled version of the General Health Questionnaire (GHQ-28) in a Spanish population. Psychological Medicine, 16(1), 135-140. https://doi.org/10.1017/ S0033291700002579

Malenfant, R., LaRue, A. \& Vézina, M. (2007). Intermittent Work and Well-Being. One Foot in the Door, One Foot Out. Current Sociology, 55(6) 814-835 https://doi. org/10.1177/0011392107081987

Martínez-Veiga, U. (2009). Economía informal e informalización de la sociedad. Inmigración, derechos políticos y sociales. En T. Infantez y J.E. Martínez. (eds). Economía Informal y perspectiva de género en contextos de trabajo. (33-69). Barcelona: Icaria editorial.

Moya, A. (2014). Impacto del programa "Ley del primer empleo" en la incidencia en la informalidad y en el subempleo juvenil en Colombia. Suma de Negocios, 4(2), 9711. http://publicaciones.konradlorenz.edu.co/index.php/ SumaDeNegocios/article/download/1523/889
McDowell, L., Batnitzky, A. \& Dyer. S. (2009). Precarious Work and Economic Migration: Emerging Immigrant Divisions of Labour in Greater London's Service Sector. International Journal of Urban and Regional Research, 33(1), 3-25. https://doi.org/10.1111/j.1468-2427.2009.00831.x

McKee, F.M. \& Harvey, J. (2011). "I Have a Job, But...": A Review of Underemployment. Journal of Management, 37(4), 962-996. https://doi.org/10.1177/0149206311398134

Mousteri, V., Daly, M., \& Delaney, L. (2020). Underemployment and psychological distress: Propensity score and fixed effects estimates from two large UK samples. Social Science \& Medicine, 244, 112641. https://doi.org/10.1016/j. socscimed.2019.112641

International Labour Organization (2014). Estadísticas del Subempleo. Recuperado el 10 de septiembre de 2014, del sitio web de la ILO: http://www.ilo.org/global/statisticsand-databases/statistics-overview-and-topics/underemployment/lang--es/index.htm.

Paris, L. (2008). Estrés laboral asistencial, recursos de afrontamiento y satisfacción laboral en trabajadores de la salud de la ciudad de Rosario. Tesis Doctoral inédita. Facultad de Psicología, Universidad Nacional de Rosario: Rosario.

Peralta, M.C. (2011). Significados asociados al futuro laboral: entre la formalidad y la informalidad. Pensamiento Psicológico, 9(16), 107-124. https://revistas.javerianacali.edu.co/index.php/pensamientopsicologico/article/ view/168/500

Perilla, L.E. \& Gómez, V. (2017). Relación del estilo de liderazgo transformacional con la salud y el bienestar del empleado: el rol mediador de la confianza en el líder. Journal of Work and Organizational Psychology, 33(2), 95-108. http:// dx.doi.org/10.1016/j.rpto.2017.02.005

Petter Pérez, L. \& Moreno Hurtado, C. (2019). Subempleo en el mercado laboral juvenil en Ecuador. Revista nuestrAmérica, 7(13), 265-280. https://www.redalyc.org/jatsRepo/5519/551957774014/551957774014.pdf

Puyana, R., Ramos, M.A., \& Zárate, H. (2011). Determinantes del Subempleo en Colombia: Un Enfoque a Través de la Compensación Salarial. Borradores de Economía, 652, 1-41. http://www.banrep.gov.co/sites/default/files/publicaciones/pdfs/borra652.pdf

Ramírez, C.L. (2002). Panorama laboral colombiano: alto desempleo, ingresos precarios. Revista Magazín Observatorio de Coyuntura Socioeconómica, 1, 1-20.

Ramsey, M.A. \& Gentzler, A.L. (2015). An upward spiral: Bidirectional associations between positive affect and positive aspects of close relationships across the life span. Development Review, 36, 58-104. https://doi.org/10.1016/j. dr.2015.01.003

Resolución 2646 de 2008. Diario Oficial No. 47.059, Ministerio de la Protección Social, Bogotá, Colombia, 17 de julio de 2008.

Resolución 8430 of 1993. Ministerio de Salud, Santafé de Bogotá, Colombia, 4 de octubre de 1993. 
Restrepo, L., \& Rivas, P. (2013). La calidad del empleo para los hombres y las mujeres: un estudio desde la informalidad, el subempleo y las percepciones. Equidad y Desarrollo, (19), 115-135. https://doi.org/10.19052/ed.2311

Ryff, C. (1989a). Beyond Ponce de Leon and life satisfaction: New directions in quest of successful aging. International Journal of Behavioral Development, 12(1), 35-55. https:// doi.org/10.1177/016502548901200102

Sandín, B., Chorot, P., Lostao, L., Joiner, T., Santed, M. \& Valiente, R. (1999). Escalas PANAS de afecto positivo y negativo: validación factorial y convergencia transcultural. Psicothema, 11(1), 37-51. http://www.psicothema.com/ pdf/229.pdf

Shouksmith, G. (1990). A construct validation of a scale for measuring work motivation. New Zealand Journal of Psychology, 18(2), 76-81.

Siegrist, J. (2002). Effort-reward imbalance at work and health. En D.C. Ganster (ed.) Historical and Current Perspectives on Stress and Health, Research in Occupational Stress and Well-being (Volume 2, 261-291). https://doi.org/10.1016/ S1479-3555(02)02007-3

Tam, H. (2010). Characteristics of the underemployed and the overemployed in the UK. Economic \& Labour Market Review, 4(7), 8-20. https://doi.org/10.1057/elmr.2010.92

Thompson, K., Shea, T., Sikora, D., Perrewe, P. \& Ferris, G. (2013). Rethinking Underemployment and Overqualification in Organizations: The Not so Ugly Truth. Business Horizons, 56(1), 113-121. https://doi. org/10.1016/j.bushor.2012.09.009

Tokman, E. (2009). Flexiguridad con informalidad: opciones y restricciones. En: J. Weller (ed). El nuevo escenario laboral latinoamericano. (pp. 255-287). Buenos Aires: Siglo Veintiuno Editores.

Verbruggen, M.; Van Emmerik, H.; Van Gils, A.; Meng, C., de Grip, A. (2015). Does early-career underemployment impact future career success? A path dependency perspective. Journal of Vocational Behaviour, 90, 101-110. https://doi. org/10.1016/j.jvb.2015.08.002
Walling, A., \& Clancy, G. (2010). Underemployment in the UK labour market. Economic and Labour Market Review, 4(2), 16-24. http://dx.doi.org/10.5296/jsss.v1i2.5101

Watson, D., Clark, L. A. \& Tellegen, A. (1988). Development and validation of brief measures of positive and negative affect: The PANAS Scales. Journal of Personality and Social Psychology, 54(6), 1063-1070. https://doi. org/10.1037/0022-3514.54.6.1063

Wilkins, R. (2007). The Consequences of Underemployment for the Underemployed. Journal of Industrial Relations, 49(2) 247-275. https://doi.org/10.1177/0022185607074921

Wilkins, R. \& Wooden, M. (2011). Economic Approaches to Studying Underemployment. En D. Maynard y D. Feldman (Ed.) Underemployment (pp. 13-34). New York: Estados Unidos: Springer.

Winefield, A.H. (2002). Unemployment, Underemployment, Occupational Stress and Psychological Well-Being. Australian Journal of Management, 27(1), 137-148. https:// doi.org/10.1177/031289620202701S14

Winefield, A.H., Tiggemann, M., \& Winefield, H. (1991). The Psychological Impact of Unemployment and Unsatisfactory Employment in Young Men and Women: Longitudinal and Cross-sectional data. British Journal of Psychology, 82(4), 473-486. https://doi.org/10.1111/j.2044-8295.1991. tb02414.x

\section{Declarations}

Availability of data and material: The datasets used during the current study are available from the corresponding author on reasonable request.

Competing interests: The authors declare that they have no competing interests.

Funding: Not applicable

Authors' contributions: The manuscript is a joint work of the two coauthors; both the authors have read and approved the final manuscript. 